\title{
The Big Mac Index And Real-Income Disparity
}

Vidya Atal, Montclair State University, USA

\begin{abstract}
The Big Mac Index was introduced to (semi-humorously) test the theory of purchasing power parity and measure the disparity in currency values. Instead, in this paper, we consider this index to find out the per capita real-income disparity across 54 countries. We find that the per capita real-income can be very low in some countries even when Big Mac burgers are very cheap, like in India. Among these countries, Hong Kong's per capita Big Mac affordability is the highest with 47 burgers daily whereas Pakistan's people could afford just one a day. Additionally, we find that Russia and China's Big Mac affordability has been significantly increasing over the last decade, Brazil's has remained more or less constant, however USA's Big Mac affordability has been falling, indicating that per capita real-income of Americans has been decreasing over the last decade. Finally, we find that increased role of the government might be negatively correlated to per capita real-income. Czech Republic has been experiencing increased Big Mac affordability as the country has been reducing the government's role; whereas Argentina has been experiencing reduced Big Mac affordability as the country has been moving left and increasing the government's power.
\end{abstract}

Keywords: Big Mac Index; Purchasing Power; Affordability; Real-Income Disparity

\section{INTRODUCTION}

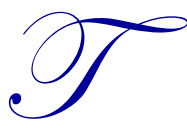

he theory of Purchasing Power Parity predicts that, in the long-run, the exchange rate of currencies would be such that a market basket of goods would cost exactly the same in a particular currency (say US dollars) across all countries. The Economist introduced the Big Mac Index in 1986 to test this theory in a "light-hearted" way where the market basket consisted of only one commodity---the Big Mac burger by the famous fast-food chain McDonald's. Since then, they have been publishing this index every year as an indicator of how over or under-valued a country's currency has been compared to the US dollars.

In this paper, we take the Big Mac Index one step further and compare it to the GDP per capita for 54 countries for the year 2012. This provides us with a rough estimate about a country's "affordability index," by finding out how many Big Mac burgers can an average person afford daily in a country. We also check the intertemporal growth in Big Mac affordability for Brazil, China, Russia, and USA during the year 2000-2012. ${ }^{1}$ Finally we compare the inter-temporal growth in Big Mac affordability for Czech Republic and Argentina to see how the difference in government policies can lead to different outcomes in the growth of the countries' real-incomes.

Burgernomics is taken much more seriously nowadays than what it was intended for. The Economist has been publishing annual reports on the Big Mac Index since 1986. They have also come up with an "adjusted index" that gives the error from the best line of fit between the Big Mac prices and PPP adjusted GDP per capita. Daley (2008) related Big Mac prices to investment returns. Politi (2011) mentioned that Argentina's government were controlling Big Mac's price and indicated that they might have been manipulating their economic data.

The analysis in our paper is more closely related to Hoefert and Hofer (2006). They found out how many hours an average worker had to work to earn enough to buy a Big Mac burger in a country. This gives us some

\footnotetext{
${ }^{1}$ Lack of enough Big Mac price data for India has lead us to drop the country from showing the growth in real-income.
} 
information on the wage-rate disparity across countries. As opposed to that, we are interested in finding out about the affordability of Big Macs across countries to measure the per-capita real income disparity. This analysis tells us that a "cheap" burger is not necessarily an affordable burger when per capita income is factored in.

We then plot the Big Mac affordability for three developing economies and USA over the years 2000-2012. We find that it has been increasing for China and Russia and has remained more or less constant for Brazil. However, it has been significantly decreasing in USA indicating a decrease in Americans' real-income over the last decade. Finally, we plot the Big Mac affordability for Czech Republic and Argentina to see the role that the government's power plays in the growth of per capita real-income. We find that the Big Mac affordability is increasing in Czech Republic as they are reducing the power of the government whereas the affordability has been decreasing in Argentina as they are increasing the government's power.

\section{BIG MAC AFFORDABILITY AND REAL-INCOME DISPARITY}

We find the Big Mac "affordability" by dividing the 2012 GDP per capita (in US dollars) for 54 countries by their respective Big Mac prices in July 2012. ${ }^{2}$ To get the daily affordability, we then divide this number by 366 and compare the number across 54 countries. This gives us information on the per capita real-income disparity. The results are shown in Table 1.

Table 1: The Big Mac affordability across 54 Countries in 2012

\begin{tabular}{|c|c|c|c|}
\hline Country & GDP per Capita (USD) & Big Mac Price & Big Mac Afford-Ability \\
\hline Hong Kong & $36,676.30$ & 2.13 & 47.12 \\
\hline Singapore & $52,051.81$ & 3.50 & 40.68 \\
\hline Australia & $67,304.47$ & 4.68 & 39.29 \\
\hline Norway & $99,170.20$ & 7.06 & 38.39 \\
\hline United Arab Emirates & $43,773.84$ & 3.27 & 36.61 \\
\hline Denmark & $56,426.45$ & 4.65 & 33.19 \\
\hline Austria & $46,642.88$ & 3.87 & 32.95 \\
\hline Switzerland & $78,880.93$ & 6.56 & 32.85 \\
\hline United States & $51,703.95$ & 4.33 & 32.64 \\
\hline Israel & $33,432.68$ & 2.92 & 31.29 \\
\hline Japan & $46,706.72$ & 4.09 & 31.19 \\
\hline Netherlands & $46,010.95$ & 4.10 & 30.68 \\
\hline Ireland & $45,984.37$ & 4.23 & 29.69 \\
\hline Canada & $52,299.76$ & 5.02 & 28.45 \\
\hline Finland & $45,634.93$ & 4.55 & 27.43 \\
\hline Sweden & $54,814.80$ & 5.73 & 26.14 \\
\hline New Zealand & $38,254.62$ & 4.00 & 26.10 \\
\hline Germany & $41,865.52$ & 4.41 & 25.92 \\
\hline Belgium & $43,615.17$ & 4.61 & 25.87 \\
\hline France & $41,223.31$ & 4.36 & 25.81 \\
\hline United Kingdom & $39,160.58$ & 4.16 & 25.71 \\
\hline Saudi Arabia & $24,523.92$ & 2.67 & 25.13 \\
\hline Taiwan & $20,335.92$ & 2.48 & 22.37 \\
\hline Italy & $33,115.01$ & 4.36 & 20.73 \\
\hline Greece & $22,072.45$ & 3.25 & 18.54 \\
\hline Estonia & $16,720.16$ & 2.47 & 18.47 \\
\hline Spain & $28,670.09$ & 4.24 & 18.46 \\
\hline Russia & $14,302.09$ & 2.29 & 17.07 \\
\hline Czech Republic & $18,624.30$ & 3.34 & 15.23 \\
\hline Lithuania & $14,009.01$ & 2.74 & 13.98 \\
\hline Poland & $12,709.27$ & 2.63 & 13.20 \\
\hline
\end{tabular}

${ }^{2}$ The data on 2012 GDP per capita was gathered from the World Economic Outlook Database (October 2013) by the International Monetary Fund and the data on Big Mac prices was gathered from The Economist (January 2014) and the website http://bigmacindex.org/2012-Big-MacIndex.html. 
Table 1 cont.

\begin{tabular}{|l|c|c|c|}
\hline Latvia & $13,899.89$ & 2.94 & 12.91 \\
\hline Malaysia & $10,344.87$ & 2.33 & 12.12 \\
\hline Costa Rica & $9,665.03$ & 2.40 & 10.17 \\
\hline Mexico & $10,058.50$ & 2.70 & 10.13 \\
\hline Chile & $15,410.12$ & 4.16 & 9.92 \\
\hline Hungary & $12,652.04$ & 3.48 & 9.12 \\
\hline Portugal & $20,037.74$ & 6.00 & 8.91 \\
\hline Uruguay & $14,766.83$ & 4.53 & 7.61 \\
\hline South Africa & $7,525.39$ & 2.36 & 6.77 \\
\hline Argentina & $11,582.48$ & 4.16 & 6.37 \\
\hline China & $6,071.47$ & 2.45 & 6.29 \\
\hline Turkey & $10,526.80$ & 4.52 & 5.71 \\
\hline Brazil & $11,358.54$ & 4.94 & 5.69 \\
\hline Ukraine & $3,877.28$ & 1.86 & 4.54 \\
\hline Thailand & $5,390.41$ & 2.59 & 4.46 \\
\hline Colombia & $7,919.17$ & 4.77 & 3.85 \\
\hline Venezuela & $12,917.52$ & 7.92 & 3.55 \\
\hline Indonesia & $3,593.67$ & 2.55 & 3.22 \\
\hline Sri Lanka & $2,875.80$ & 2.21 & 2.59 \\
\hline Egypt & $3,111.87$ & 2.64 & 2.55 \\
\hline India & $1,500.76$ & 1.58 & 1.14 \\
\hline Philippines & $2,611.50$ & 2.80 & 3.01 \\
\hline Pakistan & $1,260.74$ & & \\
\hline
\end{tabular}

We find that people in Hong Kong could afford the maximum number of Big Mac burgers---more than 47 a day (their currency was undervalued by 50\% in 2012 according to Burgernomics). People in the United States could afford more than 32 burgers daily and UK could afford 25 burgers (British pounds were undervalued by almost $4 \%$ according to the raw Big Mac index). Singapore, Australia, Norway, and Euro-zone countries could afford more than 25 Big Macs per capita daily. However, if we look at the BRIC countries, Russia was doing the best with 17 burgers daily per capita along with $47 \%$ currency under-valuation. Brazil and China could afford 6 Big Macs per capita daily whereas Brazil's Real was over-valued by $14 \%$ and China's Yuan was under-valued by $43 \%$. Among the BRIC countries, Indians could afford the least number of Maharaja Burgers ${ }^{3}$ with less than 3 burgers per capita daily (Rupee was under-valued by 63\%). If we consider all the 54 countries, only Philippines and Pakistan came after India, with 2.5 and 1.1 burgers daily per capita, respectively.

Our results suggest that although Big Mac burgers are very cheap (in terms of US dollars) in some countries, people there could hardly afford them. Our analysis gives an indication of a huge real-income disparity across countries.

Next, we gather information on GDP per capita (in current US dollars) for three of the BRIC countries (dropping India for lack of Big Mac price data) and make a side-by-side comparison between the Big Mac affordability for each of these countries over the years 2000-2012. ${ }^{4}$ We divide the GDP per capita by the mid-year Big Mac price in the corresponding country and then divide it by $365 .{ }^{5}$ The plots are shown in Figure 1.

\footnotetext{
${ }^{3}$ Maharaja Burger in India is considered their Big Mac equivalent, which is made of chicken instead of beef, according to Burgernomics.

${ }_{5}^{4}$ Data on GDP per capita from 2000-2012 was collected from the World Bank.

${ }^{5} 366$ for a leap year.
} 


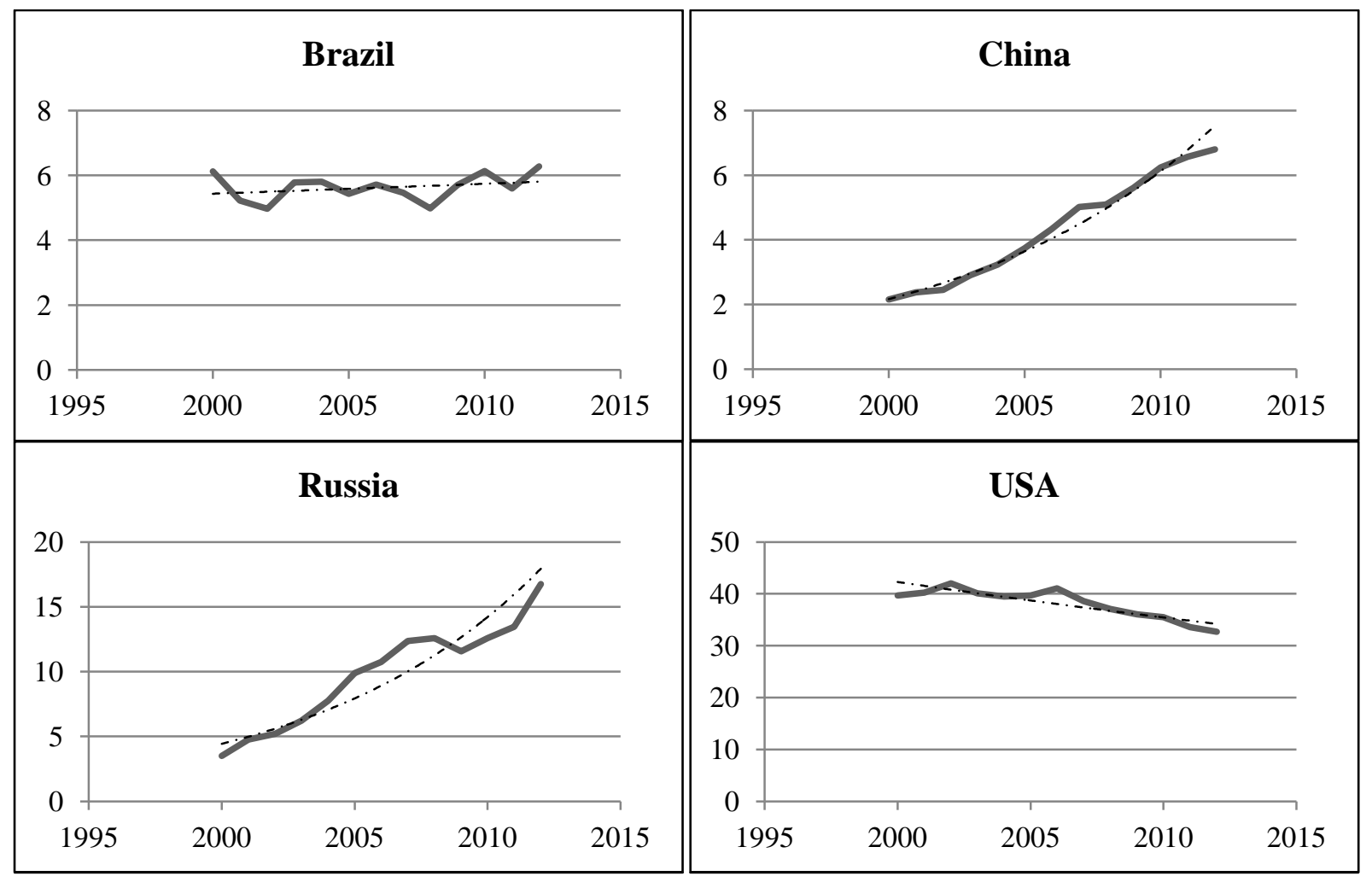

Figure 1: Big Mac Affordability across Countries during 2000-2012 and the Growth in Real-Income

We find that over the thirteen years we are considering, the Big Mac affordability has been increasing at an increasing rate in Russia and China, with Russians being able to afford more Big Macs than Chinese. Big Mac affordability in Brazil has been fluctuating a lot over time, with the average trend being more or less the same at 5.6 burgers daily. However, USA's Big Mac affordability has been decreasing significantly over time. An average American could afford 39.7 burgers daily in 2000; the number increased to 42 burgers in 2003 and then almost steadily fell to 32.7 burgers daily in 2012. One can blame the great recession for this. It also raises the concern that, however insignificant the rate of inflation in USA has been, the nominal wages are not catching up with the inflation and people are losing their incomes in real terms.

We next find out the Big Mac affordability for Czech Republic and Argentina for the years 2000-2012 and plot the data side-by-side. Over this time period, Argentina has expanded the role of the government in their economy whereas Czech Republic has reduced it. As evident from Figure 2, we find that the Big Mac affordability has been increasing in Czech Republic and it has been decreasing in Argentina. This suggests that the growth in Big Mac affordability might be negatively correlated to the growth in the government's role in an economy indicating its negative impact on the per capita real-income. 


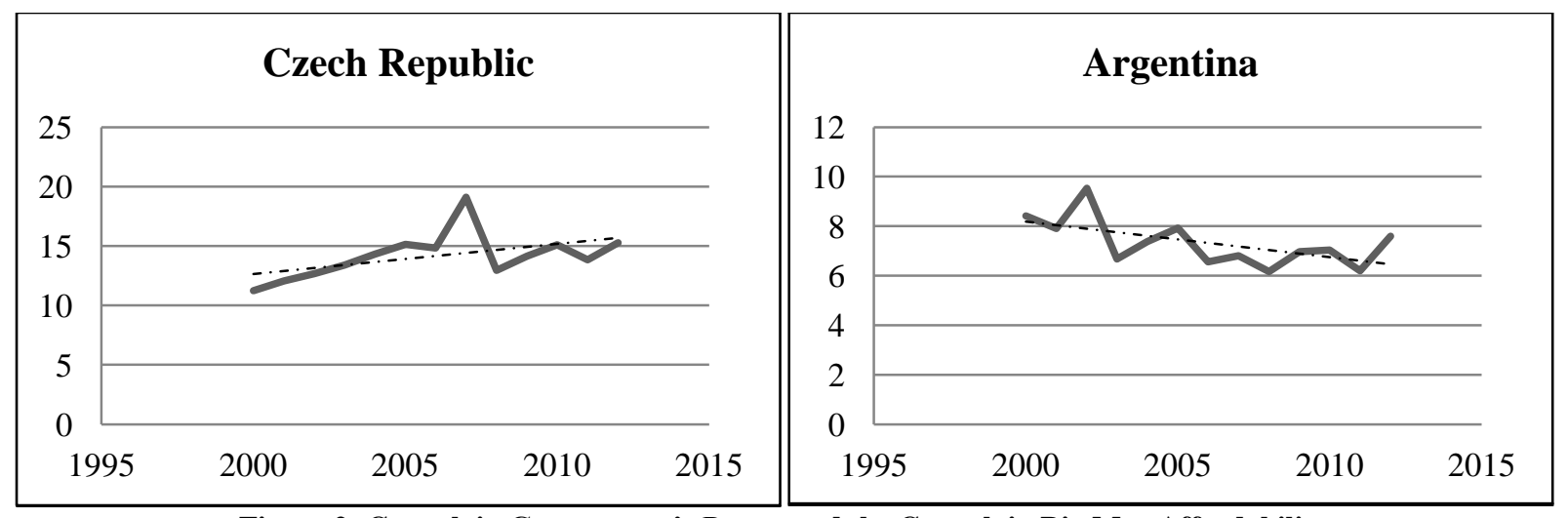

Figure 2: Growth in Government's Power and the Growth in Big Mac Affordability

\section{CONCLUSION}

Burgernomics was introduced to semi-humorously test the theory of purchasing power parity. According to this, a Big Mac burger's price should be the same in a particular currency across countries in the long-run. However, The Economist found that in 2012 it was priced between $\$ 1.58$ and \$7.92, being available the cheapest in India and the most expensive in Venezuela. A layperson's view from this data without its context may be biased towards thinking that the cheaper it is, the better it is for a country. However, that is hardly the case. In fact, it indicates that a currency is over-valued or under-valued compared to another currency. Even if we consider just the cheapness of the burger, it does not mean it is more affordable in that country. It depends upon the GDP per capita (or an equivalent measure).

We considered this data from 2012 (the latest available aggregate data) and found out how many Big Mac burgers an average resident of a country could afford to buy daily for 54 countries. We found that, across countries, although it was the cheapest in India, people there could not even afford three burgers a day. Pakistan had the lowest Big Mac affordability, followed by Philippines and then India, whereas Hong Kong had the highest Big Mac affordability followed by Singapore and then Australia.

We also made a cross country comparison in the growth of Big Mac affordability for Brazil, China, Russia, and USA and then for Czech Republic and Argentina over the years 2000-2012. We found that the average affordability has been increasing for China and Russia whereas it is decreasing in USA. This raises a concern that average Americans might have been losing their income over time in real terms. We also found that the average Big Mac affordability has been increasing in Czech Republic and has been decreasing in Argentina. This raises a suspicion that the increased role of the government in Argentina might have a negative impact on its per capita realincome.

\section{ACKNOWLEDGEMENT}

I am grateful to Souptik Datta, Luis San Vicente Portes, and the referees for insightful conversation and comments.

\section{AUTHOR INFORMATION}

Vidya Atal is an Assistant Professor in the Department of Economics and Finance at Montclair State University. She holds a Master's and a Ph.D. degree in economics from Cornell University. Her research interests include studying the patent policies in USA, open source software licensing, firms' investment decisions in R\&D, etc. In addition, she finds several other topics like female power, intra-household bargaining, and right to employment, very interesting. Dr. Atal's research articles have appeared in some of the top-tier peer-review journals, namely, the Journal of Industrial Economics, Economics Letters, International Journal of Industrial Organization, and International Journal of Economic Theory. E-mail: atalv@ mail.montclair.edu 


\section{REFERENCES}

1. Big Mac Index (2012). Retrieved January 31, 2014 from http://bigmacindex.org/2012-Big-Mac-Index.html

2. Daley, J. (2008). Burgernomics: Why the price of a Big Mac may hold the key to better investment returns. The Independent.

3. Hoefert, A., \& Hofer, S. (2006). Prices and earnings: A comparison of purchasing power around the globe. UBS AG, Wealth Management Research, pp. 11. Retrieved February 4, 2014 from http://www.ubs.com/1/ ShowMedia/ubs_ch/wealth_mgmt_ch?contentId=103982\&name=eng.pdf

4. Politi, D. (2011). Argentina's Big Mac attack. The New York Times. Retrieved February 4, 2014 from http://latitude.blogs.nytimes.com/2011/11/24/argentinas-big-mac-attack/

5. The Economist (2014). Retrieved January 31, 2014 from http://www.economist.com/content/big-mac-index

6. The World Bank Database. Retrieved February 10, 2014 from http://data.worldbank.org/indicator/NY.GDP.PCAP.CD?page=1

7. World Economic Outlook Database-October 2013, International Monetary Fund. Retrieved January 31, 2014 from http://www.imf.org/external/pubs/ft/weo/2013/02/weodata/weoselgr.aspx 